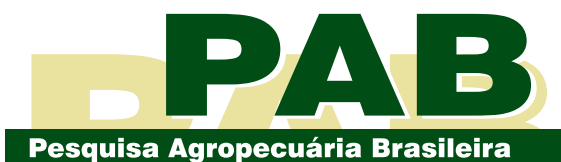

ISSN 1678-3921

Journal homepage: www.embrapa.br/pab

For manuscript submission and journal contents, access: www.scielo.br/pab

\title{
Damage caused by cattle to Eucalyptus benthamii trees in pruned and unpruned silvopastoral systems
}

\begin{abstract}
The objective of this work was to evaluate the effect of tree pruning on the incidence and intensity of the damages caused by cattle to 26-monthold Eucalyptus benthamii, in a silvopastoral system, in the municipality of Pinhais, in the state Paraná, Brazil. The experiment was performed in a randomized complete block design, with two treatments - livestock and forest with pruned eucalyptus (WP), and livestock and forest with unpruned eucalyptus (UP) - and three replicates, characterizing six types of damages and five damage intensities. There were significant differences between the WP and UP treatments for the different types of damages. Cattle entry in the silvopastoral system at 26 months after the planting of eucalyptus causes lowintensity damages to the trees, in the treatment with pruning, and mediumintensity damages to the trees in the treatment without pruning. Damages of stronger intensities were detected in the UP treatment, in which classtwo damages ( $\mathrm{d} 2$ = average damage) were verified in approximately $91 \%$ of the trees. The silvicultural practice of pruning E. benthamii trees does not affect the diameter at breast height or the total height of trees. Pruning can be recommended, as it does not affect tree development; moreover, this practice enables the production of knot-free, better-quality wood.
\end{abstract}

Index terms: diameter at breast height, forest, forestry, quality wood.

\section{Danos causados por bovinos a Eucalyptus benthamii, com ou sem desrama, em sistemas silvipastoris}

Resumo - O objetivo deste trabalho foi avaliar o efeito da desrama sobre a incidência e intensidade de danos causados por bovinos a Eucalyptus benthamii aos 26 meses de idade, no município de Pinhais, no estado do Paraná, Brasil. O experimento foi feito em um delineamento de blocos ao acaso, com dois tratamentos - pecuária-floresta com eucaliptos desramados (WP) e pecuária-floresta com eucaliptos sem desrama (UP) - e três repetições, que caracterizaram seis tipos de danos e cinco intensidades. Houve diferenças significativas entre os tratamentos WP e UP para os diferentes tipos de danos. A entrada de bovinos no sistema silvipastoril, 26 meses após o plantio de eucalipto, causa danos de baixa intensidade às árvores, no tratamento com desrama, e danos de média intensidade às árvores no tratamento sem desrama. Danos de maiores intensidades foram registrados no tratamento UP, em que o dano de classe dois ( $\mathrm{d} 2=$ dano médio) foi verificado em aproximadamente $91 \%$ das árvores. A prática silvicultural de desrama das árvores de $E$. benthamii não afeta o diâmetro à altura do peito nem a altura total das árvores. A desrama pode ser recomendada, já que não influencia o desenvolvimento 
das árvores; além disso, essa prática possibilita a produção de madeira sem nós, de melhor qualidade.

Termos para indexação: diâmetro à altura do peito, floresta, silvicultura, madeira de qualidade.

\section{Introduction}

The interest in silvopastoral and agroforestry systems has increased significantly in Brazil. Practices such as livestock and forestry integration ensued after research and extension programs, which were fostered by the Brazilian federal government, such as the low-carbon agriculture program ("Agricultura de Baixo Carbono", ABC Program), created in 2010, and the "Integra SP" project, designed in 2013 in São Paulo state.

Silvopastoral systems (SPS) integrate livestock and timber production in the same area. The association of adequately managed trees with pastures may provide an extra source of income for the farmer, as well it may improve environmental protection and promote animal welfare, while increasing soil fertility and pasture production (Porfírio-da-Silva et al., 2010). It is a dynamic and complex system, since it integrates elements of different natures (Balbino et al., 2011). These systems are also considered a high-investment forest component, and their results are obtained in the long term (Kichel et al., 2014). Therefore, the selection of species and their genetic material are important points to be considered for the system to become successful.

SPS have proved to be a viable supplier of wood products and provider of additional revenues to farmers. In this sense, when SPS are adopted as a production model, the sustainability of the ecosystem as a whole should be expected, instead of the maximum productivity of singular components (Bernardi et al., 2014).

The establishment of tree seedlings in a pasture area represents a critical phase for SPS. This step of the implementation process requires specific attention as any damage caused to the trees at this stage of their development may compromise the system's success (Porfírio-da-Silva et al., 2010).

Even after the trees are grown sufficiently to support the presence of cattle in a given area, tree bark damages can still be caused by the animals (Medrado et al., 2009; Porfirio-da-Silva et al., 2012; Guerreiro et al., 2015). Tree bark damage depreciates the wood quality and may even lead to tree death.

The factors or causes for the removal of eucalyptus bark by cattle are unknown. The suggested hypotheses to explain this type of animal behavior are related to the animal's nutritional state (deficiencies in certain minerals, protein, and energy), to the concentration and quality of ingested fibers (Malafaia et al., 2011; Villalba et al., 2014), to the presence of endoparasites (Saint-Andrieux et al., 2009; Villalba et al., 2013), and, also, to behavioral aspects of the animals (Berridge \& Kringelbach, 2008).

Potential factors that influence cattle seeking different sources of food in tree species, and not in forage, may be linked to the quality and quantity of forage available to the animals, according to Brun et al. (2017). These authors also mention that forage quality and quantity are linked to genetic factors related to the selection of forage species / varieties appropriate for each animal species or breed, and to the quality of the soil, which is the basis for the development and nutritional quality of forages.

Tree pruning is a silvicultural practice commonly recommended for the production of quality logs and for the mitigation of competition for light from treetops. Besides improving wood quality for sawmills, pruning favors animal movement and allows a greater availability and uptake of radiation among tree lines, contributing to the maintenance or even to the increase of pasture productivity in SPS (Fontan, 2007).

Porfírio-da-Silva et al. (2012) recommended pruning to reduce leaf damages, as well as to avoid the breaking of branches and sprouts in silvopastoral systems, since these damages allow of the entrance of pathogenic organisms and the formation of 'loose knots' which depreciate the wood quality.

The objective of this work was to evaluate the effect of tree pruning on the incidence and intensity of damages caused by cattle to 26-month-old Eucalyptus benthamii Maiden et Cambage, in a silvopastoral system within an EPA area, since no specific works were found in the literature for this species of eucalyptus.

\section{Materials and Methods}

The experiment is part of the project developed by the center of technological innovation for agriculture (Núcleo de Inovação Tecnológica em Agropecuária, 
NITA), of Universidade Federal do Paraná, in the Canguiri experimental farm $\left(25^{\circ} 23^{\prime} 30^{\prime \prime} \mathrm{S}, 4^{\circ} 07^{\prime} 30^{\prime \prime} \mathrm{W}\right.$, at $920 \mathrm{~m}$ altitude), in the municipality of Pinhais, in the state of Paraná, Brazil. The experimental farm is located within the Environmental Protection Area (EPA) of Rio Iraí (Paraná, 1996), in the banks of the Iraí dam.

The climate is $\mathrm{Cfb}$, according to the Köppen-Geiger's classification. The average annual precipitation ranges from 1,400 to $1,600 \mathrm{~mm}$, with no defined dry season, and the average annual temperatures range from below $18^{\circ} \mathrm{C}$, in colder months, to below $22^{\circ} \mathrm{C}$, in warmer months (IAPAR, 2014).

The soils of the area have been classified as Cambissolos (Cambisols), Latossolos (Oxisols) and their associations, with smaller portions of Organossolos (Organosols) and Gleissolos (Gleysols), according to the Brazilian Soil Classification System (Santos et al., 2018).

The experimental area was established and the current research was carried out in 2012, and the following protocol was adopted: conventional soil tillage by deep plowing and a subsequent harrowing in June and July; correction of soil acidity, using 10 $\mathrm{Mg} \mathrm{ha}^{-1}$ limestone, plus sewage sludge treated by the $\mathrm{N}-$ VIRO process, obtained from the sewage treatment company of the municipality of Curitiba, in the state of Paraná, Brazil, in July and August; sowing of $80 \mathrm{~kg}$ $\mathrm{ha}^{-1}$ seeds of the 'IAPAR 61' black oat (Avena strigosa) for soil cover; and fertilization with $450 \mathrm{~kg} \mathrm{ha}^{-1}$ single superphosphate on the sowing line.

In January and February 2013, a conventional soil preparation for the sowing of perennial summer pasture was carried out. Megathyrsus maximus 'Aries' was seeded in lines $\left(16 \mathrm{~kg} \mathrm{ha}^{-1}\right)$, and $350 \mathrm{~kg} \mathrm{ha}^{-1}$ single superphosphate plus $800 \mathrm{~kg} \mathrm{ha}^{-1}$ ammonium chloride were applied to the line. During the pasture establishment phase, mowings were performed three times to reduce weed competition.

In September 2013, the tree lines were marked, and Eucalyptus benthamii seedlings of seminal origin, produced in tubes, were planted in October 2013. This species was chosen mainly due to its resistance to frost, and to its use as a final product for logs and rolling mills at the end of the 20 -year cycle.

Eucalyptus trees were planted in single rows with $14 \mathrm{~m}$ spacing between rows and $2 \mathrm{~m}$ spacing between plants, with the aim at obtaining an initial density of
357 trees per hectare. The trees were planted in contour lines to conserve soil and water and to control erosion, as well as to improve the animals' thermal comfort, and to mitigate the impact of tracks made by animals walking on terrain slopes (Porfírio-da-Silva et al., 2010).

The sowing line was subsoiled at $40 \mathrm{~cm}$ depth. The trees were then planted manually using a hoe. Next, $250 \mathrm{~mL}$ of a hydrogel solution (commercial brand Hidrogel HyB, Hidroplan-EB, São Paulo, SP, Brazil) were applied to each seedling, according to the manufacturer's recommendations. Subsequently, 200 g N-P $\mathrm{O}_{5}-\mathrm{K}_{2} \mathrm{O}(08-20-20)$ containing $1 \%$ calcium $(\mathrm{Ca})$ and 3\% sulfur (S) were applied in two lateral pits (15 $\mathrm{cm}$ away from the seedling and $15 \mathrm{~cm}$ deep).

The fertilization procedure was based on the soil analysis. In the first year (2013), fertilizers were applied in two stages: the first application was performed in September, using $450 \mathrm{~kg} \mathrm{ha}^{-1}$ single superphosphate and $400 \mathrm{~kg} \mathrm{ha}^{-1} \mathrm{~N}-\mathrm{P}_{2} \mathrm{O}_{5}-\mathrm{K}_{2} \mathrm{O}$ of the formulation 25-00-25; and the second application was performed in October, using $200 \mathrm{~kg} \mathrm{ha}^{-1}$ urea on the soil's surface.

In 2014, fertilizers were applied in three stages. In the first stage, the fertilization was performed in the second fortnight of May, using $600 \mathrm{~kg} \mathrm{ha}^{-1}$ natural phosphate, $200 \mathrm{~kg} \mathrm{ha}^{-1}$ potassium chloride, and 200 $\mathrm{kg} \mathrm{ha}^{-1}$ urea, after the winter pastures (oats) were planted. In the second stage, in September, $450 \mathrm{~kg} \mathrm{ha}^{-1}$ single superphosphate were applied. In the third stage, in November, $450 \mathrm{~kg} \mathrm{ha}^{-1}$ urea were applied to the soil's surface.

In 2015, fertilizers were applied in two stages. In the first stage, the application occurred in the second fortnight of May, after the winter pastures (oats) were planted, using $300 \mathrm{~kg} \mathrm{ha}^{-1}$ natural phosphate, $100 \mathrm{~kg} \mathrm{ha}^{-1}$ potassium chloride, and $300 \mathrm{~kg} \mathrm{ha}^{-1}$ urea. In the second stage, $200 \mathrm{~kg} \mathrm{ha}^{-1}$ urea were applied to the soil's surface at the end of December.

The use of herbicides is not allowed in EPA areas. Therefore, the weed control was performed manually using hoes and motorized brush cutters, during the first 120 days after seedlings were planted. During the seedling planting process, replanting was necessary for about $20 \%$ of the experiment's trees, as some seedling deaths occurred mainly because of plant competition and ant attacks.

Ant control was done by applying the Formifuu paste (Formifuu, Veranópolis, RS, Brazil) to all 
seedlings after 15 days of planting. In addition, orange peels were distributed weekly on strategic locations, both in the area and on its outskirts, to attract ants and reveal the location of their nests, which were then mechanically destroyed.

In July 2015, the first tree pruning under the WP treatment was performed. The branches up to half of each tree's height were removed, since as the trees had already exceeded $6 \mathrm{~cm}$ mean diameter at breast height (DBH), considered as the minimum size necessary to support the presence of cattle without breaking the trunk of the tree (Medrado et al., 2009; Porfírio-daSilva et al., 2012).
The animals entered the experiment when the trees were at 26 months of age and featuring $10.41 \mathrm{~cm}$ mean DBH (December 2015).

The experimental area that was 4.8 ha was divided, using an electric fence, in three paddocks that ranged from 1.3 to 1.8 ha each (Figure 1). The animals had water and mineralized salt freely available in all paddocks.

The experiment was carried out in a randomized complete block design with two treatments, pruned eucalyptus (WP) and unpruned eucalyptus (UP), and six types of damage, with three replicates (paddocks)

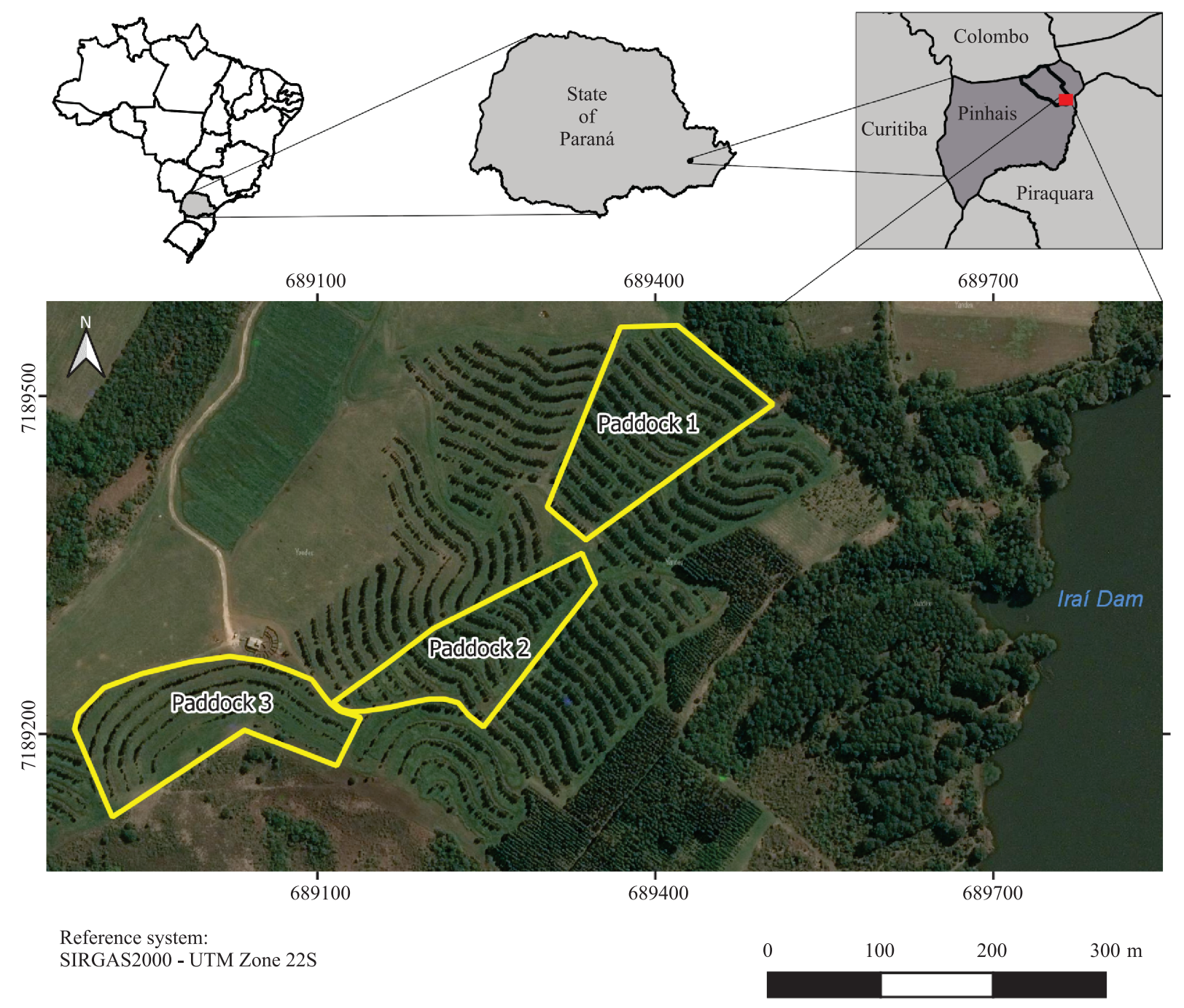

Figure 1. Distribution of Eucalyptus benthamii in the experimental area, at the Canguiri experimental farm of Universidade Federal do Paraná, in the municipality of Pinhais, in the state of Paraná, Brazil, 2016. 
from 1.3 to 1.8 ha each. The blocks were defined according to differences for the soil-slope types.

The animals used in the experiment were of no specific breed; they had $285 \mathrm{~kg}( \pm 54 \mathrm{~kg})$ mean live weight and ages ranging from 1 to 3 years. The animals were distributed in the paddocks considering their average weight, in order to keep the animal load proportional to the supporting capacity of the paddocks.

The grazing period started on 11/27/2015 and ended on 04/13/2016, totaling 138 grazing days. It was managed under continuous stocking, with variable animal load (Mott \& Lucas, 1953), and the pasture was maintained at $28 \pm 5 \mathrm{~cm}$ average height.

A systematic inventory was performed on $10 \%$ of the trees, before and after the animals' arrival on the experiment; and DBH and total height were measured at the beginning and at the end of the grazing period. The DBH and height mean of the trees at 26 months of age, in December 2015, were respectively of $10.23 \mathrm{~cm}$ and $9.37 \mathrm{~m}$ under the UP, and of $10.59 \mathrm{~cm}$ and $9.15 \mathrm{~m}$ under the WP treatment.

The paddock treatments were distributed by alternating lines of WP and UP trees, and 1,142 trees were evaluated, 594 of which under the WP treatment, and 548 under the UP treatment.

The tree damages caused by cattle were evaluated at the end of the grazing period (April 2016), 30 months after planting. The method described by Porfírio-daSilva et al. (2012) was adopted to evaluate the damages.

The damages caused by the animals were classified according to the damaged parts (incidence) of the affected plants, as: TB, trunk breakage; TI, trunk injury reaching the wood, with removal of the cambium tissue; $\mathrm{BB}$, branch breakage; BI, bark injury not reaching the cambium tissue; SB, stem breakage and browsing on leaves; and LI, large injury (larger than $5 \mathrm{~cm}$ diameter). A weighting and scoring system was established for the different types of damages: $\mathrm{TB}=10.0$; $\mathrm{TI}=4.0 ; \mathrm{BB}=2.0 ; \mathrm{BI}=1.5 ; \mathrm{SB}=1.0$; and $\mathrm{LI}=1.0$. The criterion adopted was that of Porfírio-da-Silva et al. (2012) because it seeks to relate the type of damage and its importance for the future development of the tree.

The final score for each individual is the sum of its damages. TB was the only damage for which the maximum score of 10 was adopted, irrespectively of the occurrence of other types of damage. The occurrence of LI, TI, and BB damages was always associated with other damages.

According to the adopted criterion, five classes of damage intensity (d) were established: d0, null (no damage, score 0); d1, low (scores between 0 and 3); d2, mean (scores from 3 to 6); d3, high (scores from 6 to 10); and d4, extreme (score 10). Data were collected from all trees in the experiment (1,142 plants) to quantitatively describe and qualify the damages identified in the treatments.

All six types of damage (TB, TI, BB, BI, SB, LI), as well as the means of the damage scores $(\mathrm{d} 0, \mathrm{~d} 1, \mathrm{~d} 2, \mathrm{~d} 3$, and $\mathrm{d} 4$ ) caused by the animals were compared between and within each treatment (WP and UP), using Tukey's test, at $5 \%$ probability.

The variance of the sum of damages was analyzed for homogeneity, using Bartlett's test, to verify the normality of the data for use in assumptions for the analysis of variance, to evaluate the damages within each treatment and among treatments. The Assistat program version 7.7 beta was used for the statistical analysis (Silva \& Azevedo, 2009).

\section{Results and Discussion}

There were significant differences among the types of damage in Eucalyptus benthamii, under both the WP and UP treatments. Under the WP treatment, the damage with the highest incidence was the bark injury not reaching the cambium (BI), with 78.5\% (Figure 2).

Under the UP treatment, the damages with highest incidences were branch breakage and stem breakage and browsing on leaves that were detected in $100 \%$ of the trees. There were also a high incidence $(86.5 \%)$ of bark injury, under the UP treatment, and $68.8 \%$ large injuries - larger than $5 \mathrm{~cm}$ in diameter (Figure 2).

Eucalyptus susceptibility to bovine damage was previously reported by Medrado et al. (2009), who reported a generalized damage to Eucalyptus grandis at three years of age, in a silvopastoral system with Urochloa brizantha 'Xaraés', in the state of Paraná, Brazil. Damages in $61 \%$ of the trees increased to $92 \%$ over one year, and reached the xylem in $30 \%$ of the trees.

Guerreiro et al. (2015) evaluated the susceptibility of 10 species of eucalyptus or their clones to bovine damage, in a silvopastoral system, in the city of Brotas, in the state of São Paulo, Brazil, and observed 
significant differences for damage level between the various eucalyptus species or clones. They identified that the most affected species was Eucalyptus grandis, on which $58 \%$ of the injuries caused to the bark reached the wood.

The current study highlighted that the damage occurred mainly on tree leaves, branches, and bark. Trunk breakage was observed only in trees with DBH smaller than $6 \mathrm{~cm}$, with $2.2 \%$ incidence under the WP treatment, and $4.2 \%$ under the UP treatment. These findings coincide with the results obtained by Porfírio-da-Silva et al. (2012), who reported breakages by livestock only in trees with DBH smaller than $6 \mathrm{~cm}$.

Almost $100 \%$ of stem breakages and browsing on leaves and branch breakage were observed under the UP treatment, while the incidence of these damages was of 9.6 and $6.2 \%$ under the WP treatment, respectively (Figure 2). Stem breakages and browsing on leaves, and branch breakages, in the UP treatment, were

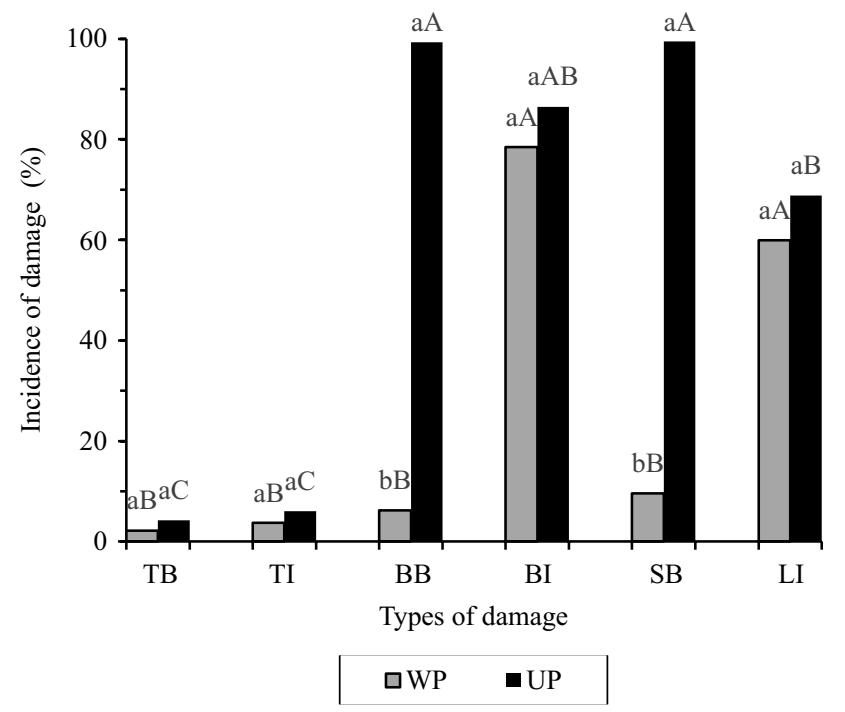

Figure 2. Incidence and types of damage caused by cattle (bovine) to Eucalyptus benthamii, in a silvopastoral system, in treatments with pruning (WP) or unpruned (UP), in the municipality of Pinhais, in the state of Paraná, Brazil, in 2016. TB, trunk breakage; TI, trunk injury reaching the wood with removal of the cambium tissue; $\mathrm{BB}$, branch breakage; BI, bark injury not reaching the cambium tissue; SB, stem breakage and browsing on leaves; and LI, large injury (larger than $5 \mathrm{~cm}$ in diameter). Means followed by equal letters, lowercase between tretments and uppercase between types of damage for the same treatment, do not differ by Tukey's test, at $5 \%$ probability. detected because some of the trees in the treatment were below the average height, which left branches and leaves exposed to cattle damages.

According to Porfírio-da-Silva et al. (2012), stem breakage and browsing on leaves should be expected in silvopastoral systems, especially when the animals are able to reach the branches. Pruning is suggested to reduce this occurrence, as well as branch breakage. Although the breaking of some leaves does not affect negatively tree development, broken branches may cause lesions that allow the access and potential attack of pathogenic organisms.

There were significant differences for damage intensity between the WP and UP treatments in Eucalyptus benthamii (Figure 3). Under the WP treatment, the damage intensity with higher incidence was $\mathrm{d} 1$, with $75.9 \%$, which is considered an intensity of low importance, while under the UP treatment, the damage intensity with higher incidence was $\mathrm{d} 2$, detected in $90.9 \%$ of the trees, which is considered of medium importance for the future development of the tree.

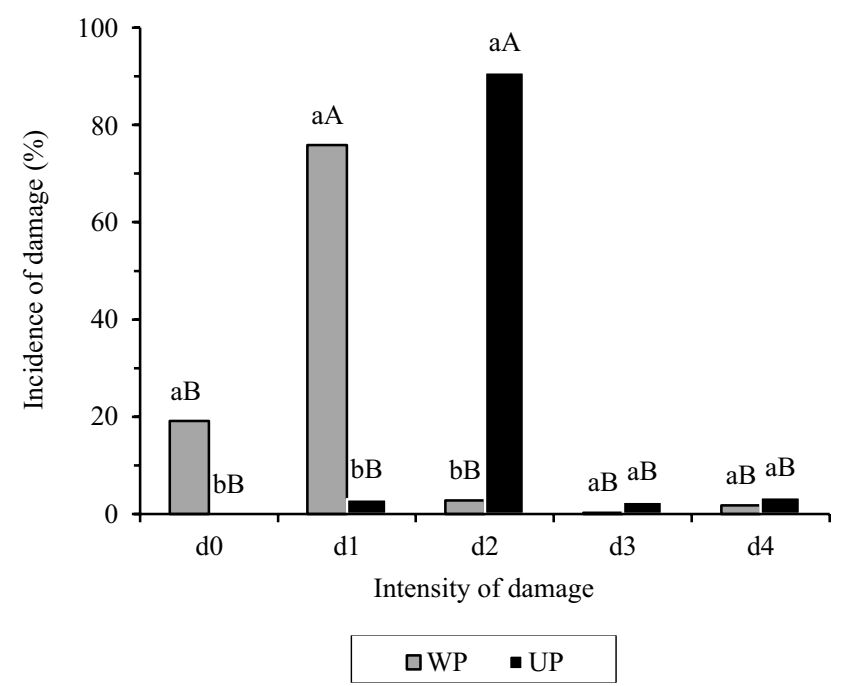

Figure 3. Incidence and intensity of damage caused by cattle (bovine) to Eucalyptus benthamii, with pruning (WP), or unpruned treatments (UP), in a silvopastoral system, in the municipality of Pinhais, in the state of Paraná, Brazil, in 2016. $\mathrm{d} 0$, null $(\mathrm{d} 0=0)$; $\mathrm{d} 1$, low $(0<\mathrm{d} 1 \leq 3)$; $\mathrm{d} 2$, medium $(3<\mathrm{d} 2 \leq 6)$; $\mathrm{d} 3$, high $(6<\mathrm{d} 3<10)$; and $\mathrm{d} 4$, extreme (d4 $=10$ ). Means followed by equal letters, lowercase between tretments and uppercase between types of damage for the same treatment, do not differ by Tukey's test, at 5\% probability. 
The tree bark performs a wide range of functions in trees. The innermost layer of the bark plays an important role in transporting and storing photoassimilates, while the outermost layer protects the plant against the ingress of pathogens and protects the adjacent tissues from mechanical injury (Romero, 2006).

The extent of the damage depends on the depth and degree of the damage to the tree bark. When the lesion is restricted to the plant's surface and does not reach the cambium tissue, the damaged part recovers evenly. In the case of a deeper damage, scarring is often only partial, with a portion of the wood becoming apparent, which may serve as a gateway for disease infection and pest attack, which may even cause death to the tree (Medrado et al., 2009). When deep lesions occur in the tree bark, a carbohydrate derived from parenchyma tissues is deposited to close the lesion (Romero, 2006). This may increase the cattle's attraction to the tree (Porfírio-da-Silva et al., 2012).

Only $19.1 \%$ of the trees under the WP treatment showed no damage (d0). All other trees underwent some type of damage (Figure 3).

Although all treatments were damaged by cattle, a significant difference was observed of the scores assigned to the different types of damages. The WP treatment showed the lowest damage score average (1.67), which qualifies its damage intensity as low; while the UP treatment, with an average score of 5.03, is classified as of medium damage intensity (Table 1).

According to Pinkard (2002), pruning decreases the photosynthetic area of the trees, and may reduce the carbohydrate supply and growth regulators produced in the canopy, therefore reducing the trees' growth in diameter and height. This effect was reported by Barbosa et al. (2014), when evaluating the impact of

Table 1. Damage caused by cattle (bovine) to Eucalyptus benthamii trees in pruning (WP) or unpruned (UP) treatments, in a silvopastoral system, and diameter at breast height (DBH) and height at 30 months, in the municipality of Pinhais, in the state of Paraná, Brazil, in 2016 ${ }^{(1)}$.

\begin{tabular}{lccc}
\hline Treatment & Damage $^{(2)}$ & DBH $(\mathrm{cm})$ & Height $(\mathrm{m})$ \\
\hline With pruning & $1.67 \mathrm{~b}$ & $11.83 \mathrm{a}$ & $10.40 \mathrm{a}$ \\
Unpruned & $5.03 \mathrm{a}$ & $11.17 \mathrm{a}$ & $9.72 \mathrm{a}$ \\
\hline
\end{tabular}

(1)Means followed by identical letters, in the same column, do not differ by Tukey's test, at $5 \%$ probability. ${ }^{(2)}$ Mean scores assigned to the different types of observed damage: nil $(\mathrm{d} 0=0)$, low $(0<\mathrm{d} 1 \leq 3)$, medium $(3<\mathrm{d} 2$ $\leq 6)$, high $(6<\mathrm{d} 3<10)$, and extreme $(\mathrm{d} 4=10)$. sheep on the trees of a silvopastoral system planted with an E. grandis $\mathrm{x}$ E. urophylla hybrid at 24 months of age; these authors observed that artificial pruning affected the growth of the trees.

In the present experiment no such difference for growth - DBH and height - of E. benthamii trees was observed between the UP and WP treatments (Table 1). At 30 months of age, the mean DBH for $E$. benthamii was $11.83 \mathrm{~cm}$ under the WP treatment, and of $11.17 \mathrm{~cm}$ under the UP treatment. The total height was $10.40 \mathrm{~m}$ under the WP treatment, and $9.72 \mathrm{~m}$ under the UP treatment. There were no significant differences for DBH and total height between the WP and UP treatments.

\section{Conclusions}

1. Cattle entry into the silvopastoral system, at 26 months after planting of Eucalyptus benthamii, causes low- and medium-intensity damages to the trees, mainly on leaves, branches, and barks, in the treatments with and without pruning, respectively.

2. The practice of pruning of Eucalyptus benthamii trees do not affect the diameter at breast height and total height of the trees, and it enables the production of knot-free, better quality wood, contributing to reduce the incidence and intensity of damages caused by cattle in the evaluated silvopastoral system.

\section{Acknowledgments}

To Coordenação de Aperfeiçoamento de Pessoal de Nível Superior (Capes, Finance code 001), and Instituto Federal Catarinense (IFC), for their financial support and scholarships.

\section{References}

BALBINO, L.C.; CORDEIRO, L.A.M.; PORFÍRIO-DA-SILVA, V.; MORAES, A. de; MARTÍNEZ, G.B.; ALVARENGA, R.C.; KICHEL, A.N.; FONTANELI, R.S.; SANTOS, H.P. dos; FRANCHINI, J.C.; GALERANI, P.R. Evolução tecnológica e arranjos produtivos de sistemas de integração lavoura-pecuáriafloresta no Brasil. Pesquisa Agropecuária Brasileira, v.46, p.i-xii, 2011. DOI: https://doi.org/10.1590/S0100-204X2011001000001.

BARBOSA, C.M.P.; GONZALEZ, L.R.; CAÇÃO, M.M. de F.; BRITO, J. de J.; SILVA FILHO, O.C. da; PORFÍRIO-DA-SILVA, V. Danos causados por ovelhas em árvores de eucalipto em um sistema silvipastoril distribuído em dois modelos espaciais. In: SIMPÓSIO INTERNACIONAL DE ARBORIZAÇÃO DE PASTAGENS EM REGIÕES SUBTROPICAIS, 1., Curitiba, 2013. 
Anais. Colombo: Embrapa Florestas, 2014. p.48-56. (Embrapa Florestas. Documentos, 268).

BERNARDI, C.M.M.; MACEDO, H.R.; PINHEIRO, R.S.B.; FREITAS, M.L.M. Florestas plantadas de eucalipto em sistemas silvipastoris e o impacto da entrada do componente animal. Revista Verde de Agroecologia e Desenvolvimento Sustentável, v.9, p.125-132, 2014.

BERRIDGE,K.C.;KRINGELBACH,M.L.Affectiveneuroscience of pleasure: reward in humans and animals. Psychopharmacology, v.199, p.457-480, 2008. DOI: https://doi.org/ 10.1007/s00213-0081099-6.

BRUN, E.J.; DALPOSSO, D.M.; KUSS, F.; SARTOR, L.R.; BRUN, F.G.K.; PERETIATKO, C.D.S. Danos causados por gado leiteiro no componente arbóreo de um sistema silvipastoril. Ecologia e Nutrição Florestal, v.5, p.33-44, 2017. DOI: https://doi.org/10.5902/2316980X25634.

FONTAN, I. da C.I. Dinâmica de copa e crescimento de clones de eucalipto submetidos a desrama em sistema agroflorestal. 2007. 68p. Dissertação (Mestrado) - Universidade Federal de Viçosa, Viçosa.

GUERREIRO, M.F.; NICODEMO, M.L.F.; PORFÍRIO-DASILVA, V. Vulnerability of ten eucalyptus varieties to predation by cattle in a silvopastoral system. Agroforestry System, v.89, p.743-749, 2015. DOI: https://doi.org/10.1007/s10457-015-9797-7.

IAPAR. Instituto Agronômico do Paraná. Atlas Climático do Paraná: classificação climática. 2014. Available at: <http:// www.iapar.br/modules/conteudo/conteudo.php?conteudo $=863>$ Accessed on: Mar. 12020.

KICHEL, A.N.; COSTA, J.A.A. da; ALMEIDA, R.G. de; PAULINO, V.T. Sistemas de integração lavoura-pecuária-floresta (iLPF) - experiências no Brasil. Boletim de Indústria Animal, v.71, p.94-105, 2014. DOI: https://doi.org/10.17523/bia.v71n1p94.

MALAFAIA, P.; BARBOSA, J.D.; TOKARNIA, C.H.; OLIVEIRA, C.M.C. Distúrbios comportamentais em ruminantes não associados a doenças: origem, significado e importância. Pesquisa Veterinária Brasileira, v.31, p.781-790, 2011. DOI: https://doi.org/10.1590/S0100-736X2011000900010.

MEDRADO, M.J.S.; PORFÍRIO-DA-SILVA, V.; DERETI, R.M.; FONSECA, L.R. da; MAIER, T.F.; PINTON, A.L.M. Danos provocados em eucalipto por bovinos criados em sistema silvipastoril no município de Cruzmaltina, PR. Colombo: Embrapa Florestas, 2009. 8p. (Embrapa Florestas. Comunicado técnico, 243).

MOTT, G.O.; LUCAS, H.L. The design, conduct, and interpretation of grazing trials on cultivated and improved pastures. In: INTERNATIONAL GRASSLAND CONGRESS, 6., 1952, State College. Proceedings. State College: Pennsylvania State College, [1953]. v.2. p.1380-1385.
PARANÁ. Decreto $n^{\circ} 1753$, de 6 de maio de 1996. [Institui a Área de Proteção Ambiental na área de manancial da bacia hidrográfica do rio Iraí, denominada APA Estadual do Iraí]. Diário Oficial [do] Estado do Paraná, 6 maio 1996.

PINKARD, E.A. Effects of pattern and severity of pruning on growth and branch development of pre-canopy closure Eucalyptus nitens. Forest Ecology and Management, v.157, p.217-230, 2002. DOI: https://doi.org/10.1016/S0378-1127(00)00647-2.

PORFÍRIO-DA-SILVA, V.; MEDRADO, M.J.S.; NICODEMO, M.L.F.; DERETI, R.M. Arborização de pastagens com espécies florestais madeireiras: implantação e manejo. Colombo: Embrapa Florestas, 2010. 48p.

PORFÍRIO-DA-SILVA, V.; MORAES, A. de; MOLETTA, J.L.; PONTES, L. da S.; OLIVEIRA, E.B. de; PELISSARI, A.; CARVALHO, P.C. de F. Danos causados por bovinos em diferentes espécies arbóreas recomendadas para sistemas silvipastoris. Pesquisa Florestal Brasileira, v.32, p.183-192, 2012. DOI: https://doi.org/10.4336/2012.pfb.32.70.67.

ROMERO, C. Tree responses to stem damage. 2006. 143p. Dissertation (Doctor) - University of Florida, [Gainesville].

SAINT-ANDRIEUX, C.; BONENFANT, C.; TOÏGO, C.; BASILLE, M.; KLEIN, F. Factors affecting beech Fagus sylvatica bark stripping by red deer Cervus elaphus in a mixed forest. Wildlife Biology, v.15, p.187-196, 2009. DOI: https://doi.org/10.2981/07-100.

SANTOS, H.G. dos; JACOMINE, P.K.T.; ANJOS, L.H.C. dos; OLIVEIRA, V.A. de; LUMBRERAS, J.F.; COELHO, M.R.; ALMEIDA, J.A. de; ARAUJO FILHO, J.C. de; OLIVEIRA, J.B. de; CUNHA, T.J.F. Sistema brasileiro de classificação de solos. 5.ed. rev. e ampl. Brasília: Embrapa, 2018.

SILVA, F. de A.S. e; AZEVEDO, C.A.V. de. Principal components analysis in the software Assistat - Statistical Assistance. In: WORLD CONGRESS ON COMPUTERS IN AGRICULTURE AND NATURAL RESOURCES, 7., 2009, Reno. Proceedings. St. Joseph: ASABE, 2009. WCCA 2009.

VILLALBA, J.J.; MILLER, J.; HALL, J.O.; CLEMENSEN, A.K.; STOTT, R.; SNYDER, D.; PROVENZA, F.D. Preference for tanniferous (Onobrychis viciifolia) and non-tanniferous (Astragalus cicer) forage plants by sheep in response to challenge infection with Haemonchus contortus. Small Ruminant Research, v.112, p.199-207, 2013. DOI: https://doi.org/10.1016/j. smallrumres.2012.11.033.

VILLALBA, J.J.; MILLER, J.; UNGAR, E.D.; LANDAU, S.Y.; GLENDINNING, J. Ruminant self-medication against gastrointestinal nematodes: evidence, mechanism, and origins. Parasite, v.21, art.31, 2014. DOI: https://doi.org/10.1051/ parasite/2014032. 